\title{
BROWNFIELDS REGENERATION, BETWEEN SUSTAINABLE URBAN DEVELOPMENT AND CULTURAL HERITAGE. THE FORMER MILITARY SITES IN ORADEA, ROMANIA
}

\author{
Cezar MORAR*, Mircea DULCA**, Gyula NAGY*** \\ *University of Oradea, ${ }^{*}$ National Military Museum - Oradea Branch, Romania, \\ ***University of Szeged, Hungary
}

\begin{abstract}
The post-Cold War conditions, following the collapse of the USSR, brought radical socio-economic changes in Central and Eastern Europe, including the process of military restructuring - a process of military relocation, which resulted in huge amounts of under-used land. Many regions are facing development dilemmas while experiencing demilitarization transformations, as the process has left behind in many cities large areas of abandoned and potentially contaminated tracts of land. The paper deals with the multitude of military brownfields redevelopment benefits, explaining the case of the city of Oradea (Romania) which implemented effective land restoration through (re)development projects in order to address the considerable contemporary demand for new lands to sustain the residential, commercial and other socio-economic needs. The cultural-historical context of the former military constructions has to be mentioned, as the involved heritage buildings have a special architecture, being a direct result of the military development process under the historical influences.
\end{abstract}

Key Words: military brownfields, sustainable (re)development, heritage buildings, Oradea, Romania.

\section{Introduction}

Across Europe, the presence of derelict and contaminated land represents a territorial concern. Brownfield sites present specific challenges to policy makers in terms of bringing the land back to beneficial use and of environmental quality, requiring the cleaning of contaminated soil and groundwater. Sustainable brownfields' redevelopment research involves integrated environmental, spatial, and urban planning approaches in configuring the suitable policies and strategies. While in North America, brownfield sites are defined as "real property, the expansion, redevelopment or reuse of which may be complicated by the presence of a hazardous substance, pollutant, or contaminant" (U.S. SENATE 2002: 504), there is no common definition for the concept of "brownfield" in Europe but the term, in general, is associated with contamination (Grimski and Ferber 2001, Cobârzan 2007). Military brownfields represent a particular category of brownfields and they are common among many countries throughout Europe.

Following the collapse of the USSR, the Central-Eastern European region experienced important socio-economic-political changes, such as: the transition from the centrally planned to the market economy, the democracy process, the institutional changes, the multi-party political system, the first free elections, the integration in the global networks (European Union, NATO), the increasing social polarization (Ilieș and Wendt 2003, Michalski 2006). This major restructuring process involved also demilitarisation, part of an important society transformation, having as consequences, among others, the emergence of the so called Military Brownfields, or underused, derelict, in some cases contaminated military areas, including abandoned buildings and the attached installations. Military Brownfields involve a large number of former military facilities, like bases, arsenals, ammunition depots, storage of fuels and lubricants, tank training areas, dump and disposal of hazardous waste. Military brownfields have a negative 
impact not only on the environment, as the site contaminants may be present in soil, in groundwater aquifers, in outdoor air, but also to the economy as well, as these abandoned areas have no contribution to the local and regional economy.

The Military Brownfield sites within the city of Oradea, in Romania, have been generated by the historical military activities and they are a mixture of military installations dating from late $19^{\text {th }}$ and $20^{\text {th }}$ centuries. At the end of the $20^{\text {th }}$ century and the beginning of the $21^{\text {st }}$ century, the whole city area was affected by the demilitarisation process. Part of these former military areas have fallen into disuse or decay with no contribution to the local economy, while other parts have had their functionality changed, from military to education or public administration services. Through new investments, the redevelopment of these valuable lands, located either central or peripheral across the city, would lead to new economic opportunities, and various social and environmental benefits, like reducing the pressure on urban or suburban greenfields (parks, forests), a better public health and an improved public safety (Russ 2000, Berman et al. 2009, Sarni 2009, De Sousa and Ghoshal 2012). In general, at local level, these sites are seen as underutilized areas, where pollution hindered their redevelopment (Oradea City Hall 2013), and their study focuses predominantly on technical elements and on environmental risk factors.

The paper deals with the multitude facets of military brownfields redevelopment benefits at local level, explaining the rehabilitation process of the former military sites as part of the city of Oradea sustainable regeneration process.

\section{Data and Methods}

The study area is represented by the former military areas (Military Brownfields, Fig. 1) of the city of Oradea, an important socio-economic and cultural urban centre, with a population of 222 736 inhabitants (INSSE 2015), located in western Romania (Bihor County), $10 \mathrm{~km}$ away from the Hungarian border, and being one of the main Romanian gateways to Central and Western Europe. The city is located at $126 \mathrm{~m}$ altitude, along the Crisul Repede River, being spatially developed at the contact between the Western Plain and the Western Hills, an area of transition between the Pannonian Depression and the Apuseni Mountain. The historical urban development of Oradea reflects the strong correlation between its spatial extension, the physical-geographical characteristics of the territory, its socio-economic features and the city's functional areas.

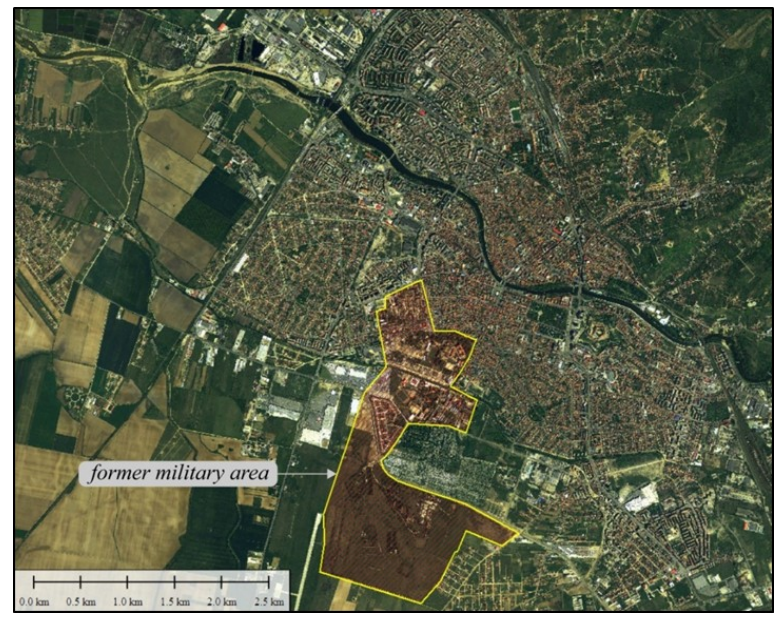

Fig. 1 - The former military areas of the city of Oradea. Source: ANCPI aerial photo (2012) 
The complexity of the research topic required a comprehensive methodology, based on the literature review in the first stage. This important phase was designed to increase the understanding of the military areas restructuring phenomenon through the results of previous research (Cocean 2005). Therefore, different types of works were reviewed, taking into account a multidisciplinary perspective - geography, sociology, architecture, history and administration studies were included. The preliminary phase meant also the analysis of maps and aerial photos for the identification and the quantitative and qualitative assessment of areas to be studied. Then, a descent into the former military areas allowed us to obtain the latest information about the status of the analysed space and related the projects undertaken by the authorities. The field observation increased the knowledge on the geographical reality of the former military areas under continuous evolution (Cocean 2005). The direct observation stage had the purpose to capture the complex characteristics of the former military areas, in order to better understand the dynamics of the involved socio-economic processes. The analysis followed with the processing of the volume of data obtained through the preceding methods. Initially, the results of the analysis are presented from a historical perspective, then they focus on the features of the military heritage buildings, presenting their specific architectural influences and style. The final phase of synthesis was the support for drawing and defining conclusions to a better policy making in the field.

\section{Results and Discussion}

From military use to commerce, service and industry activities

Oradea has developed since its beginnings in close connection to its fortress, the oldest construction within the city. The Fortress of Oradea had an important military role in the Middle Ages, but its importance was lost in the Modern Period. The evolution of the military techniques, the introduction of the mandatory military service, the need to train, to equip or to feed a large number of soldiers led, in the second half of the $19^{\text {th }}$ century, to the development of large military facilities construction projects, involving military bases, schools, ammunition depots, storage of fuels and lubricants, phenomenon quite common throughout Europe in that period.

Beginning with 1880 , on the empty field located north of the Rulikowski Cemetery, various military buildings and facilities have been built in Oradea. The School of Gendarmerie was built in 1912-1913, and its buildings host in the present time the University of Oradea (Fig. 2) (Monumente Bihor 2014). The large number of soldiers from these military facilities turned Oradea into one of the greatest military bases throughout the Austro-Hungarian Empire. Following the First World War and the union of Transylvania with Romania, all this military heritage was undertaken, with maintaining the military function by the Romanian State administration, as being the succession authority of the Austro-Hungarians in Transylvania.

Oradea hosted the $16^{\text {th }}$ Infantry Division, its commandment being in the imposing building where the General Headquarter of the School of Officers was located, during the Austro-Hungarian period (Fig. 3). The School of Gendarmerie continued its existence under the Romanian administration in the same conditions as during the Austro-Hungarian. Following the Vienna Dictate (1940), the Romanian authorities and military have redrawn from Oradea (Mândrut 2013). But, the new Romanian-Hungarian border was passing just south of Oradea, therefore the city maintained its military and strategic importance. In these conditions, it was located an important Hungarian military base in Oradea, the construction of new barracks being a real need. After 1940, there were built the military facilities of the so called "Red Barracks" (name related to the occupation of the Romanian - Soviet troops in 1944) located south of the Rulikowski cemetery. Following the Second World War, the northern part of Transylvania was reintegrated into Romania, and there were located new various Romanian military units in Oradea. Between the end of the war and 1963, the buildings presently hosting 
the University of Oradea was destined to the School of Officers for the Ministry of Interior. In 1963, the Three Years Pedagogical Institute was established there and, following 1990, the institution was converted into the University of Oradea (Paşca 2005).

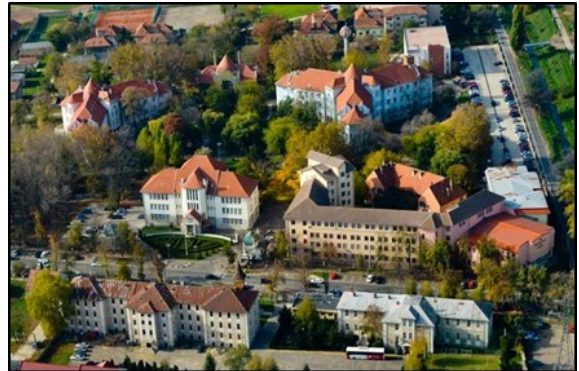

Fig. 2 - University of Oradea Main Campus

Source: www.ovidpop.ro

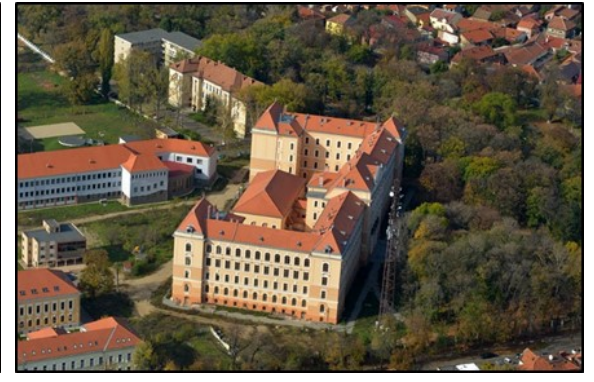

Fig. 3 - Crișuri County Museum Source: www.ovidpop.ro

After NATO was established in 1949 (NATO 1949) and the War in Korea erupted in 1950 (Britannica 2016), Stalin, the Soviet Dictator, together with the Satellite Countries from the Central-Eastern Europe, including Romania, have developed an arming program, part of the Warsaw Treaty (TOH 2016), for the endowment of the military with modern technique. So that, the Romanian Army has increased significantly its military forces and the military was equipped with modern fighting technique. Oradea had become one of the largest barracks of the country, the $11^{\text {th }}$ Infantry Division being established here, in 1951 (renamed as the $11^{\text {th }}$ Mechanised Division in 1959). This large unit of the Romanian Army included mechanized infantry units of artillery and tanks, being organized according to the Soviet model. In order to support this military fighting technique, deposits of ammunition, fuels and facilities to maintain and repair the military technique were built (Local History 2016).

Following the Romanian Revolution (1989) and the Treaty on Conventional Armed Forces in Europe (OSCE 1990), the Romanian Army started a significant program of decreasing its military forces and techniques. There were closed a large number of military units, and a part of the buildings and facilities were transferred to the local authorities, having their functionality changed in this way. In Oradea, the same phenomenon happened and a large number of sites and buildings belonging to the $11^{\text {th }}$ Mechanised Division were transferred to the local authorities.

The buildings belonging to the $11^{\text {th }}$ Mechanised Division, closed in 2005, host important institutions today, for example: the Crișuri County Museum (under rehabilitation between 20052016, located in the former Division Commandment), the Gheorghe Șincai Bihor County Library (the former military canteen), the Territorial Labour Inspectorate Bihor, or the Cadastre and Land Registration Office Bihor. The Oradea NATO HUMINT Centre of Excellence is located in facilities belonging to the 119 Research Battalion. Other facilities of the $11^{\text {th }}$ Mechanised Division, like the cavalry stables or the infirmary of the division, have fallen into decay, being demolished in the end.

The military area hosting the former $21^{\text {st }}$ Tank Regiment (or the Red Barracks), following the withdrawal of the military presence became abandoned, derelict, with wild vegetation (Fig. 4-7). This total area of 23.84 ha has a great redevelopment potential, addressing the considerable contemporary demand for new lands to sustain residential, commercial and other economic needs within Oradea. The Association of Intercommunity Development, the Oradea Metropolitan Zone and the Oradea City hall, through the Oradea Eurobusiness Park, promoted 
a project named The Industrial Park Eurobusiness II Oradea. The technical documentation was elaborated in 2011 and the reconstruction process took place between 2015-2016. The proposed development changes the land planning, which now includes 26 parcels (with areas between $5010-9524 \mathrm{~m}^{2}$ in the east and $6865-21155 \mathrm{~m}^{2}$ in the west) located on both sides of the interior road; also, a $18 \mathrm{~m}$ wide green protection belt is to be developed towards the new residential complex from the proximity. In the east side of the site, the commerce and services are the main economic activities, while in the west the lots are larger and they are designed to host production activities (light industry) and deposits/storage (Oradea City Hall 2011). This Industrial Park aims to attract businesses and investors, as their involvement in economic activities, business development, work-place creation means the redeveloping of derelict and abandoned areas, improving the overall urban life quality at local level and serving as a catalyst for a broader sustainable development phenomenon of the urban structure.

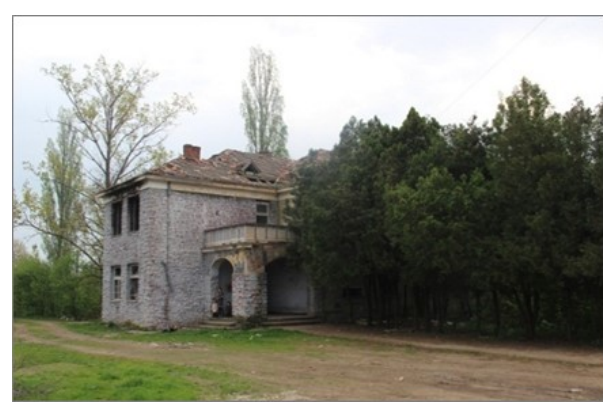

Fig. 4 - Former commandment of the $21^{\text {st }}$ Tanks Regiment

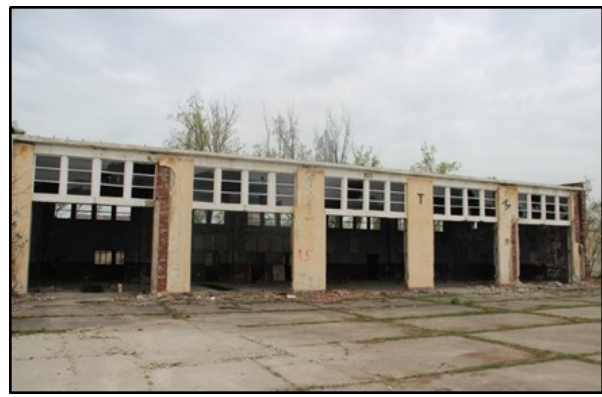

Fig. 6-The former tanks maintenance unit $\left(21^{\text {st }}\right.$ Tanks Regiment)

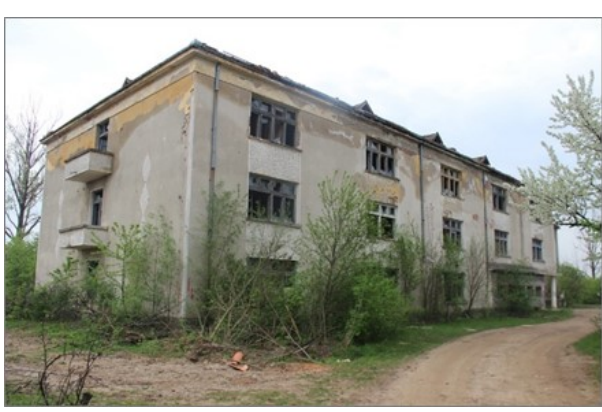

Fig. 5- Abandoned barrack of the $21^{\text {st }}$ Tanks Regiment

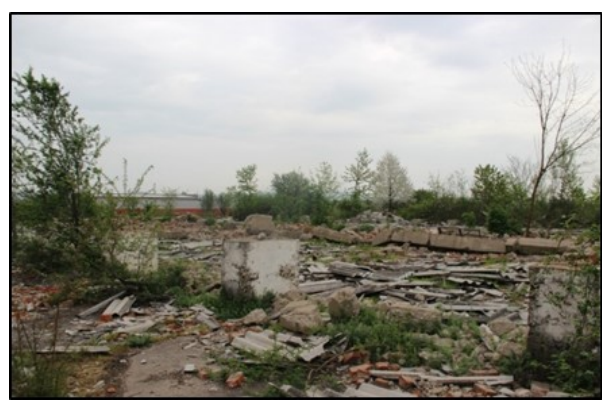

Fig. 7 - Military Brownfields in Oradea

Historical and architectural features of military heritage buildings

The former military sites of Oradea consist of historic buildings of critical value. The culturalhistorical value is very important while these heritage buildings have a special architecture as a direct result of the military development process influenced by historical events and decisions.

The former School of Gendarmerie is one of the greatest work of the architect József Vágó (Paşca 2005). The building-complex was built in 1912-1913. The main entrance is framed with two sentry-boxes $(G)$ and the buildings are centralised around a round-shaped park (Péter 2008). The former school is the main building (A) sided by the officers' house and office (D), the two major 4-storey buildings were the barracks $(B, C)$, and in-between the bath $(E)$. Behind the main buildings there are six houses for warrant officers according to Vágó's plan, yet only 
four were built $(F)$ (Fig. 8). A canteen building $(H)$ was also built in the same style and a simple white colour.
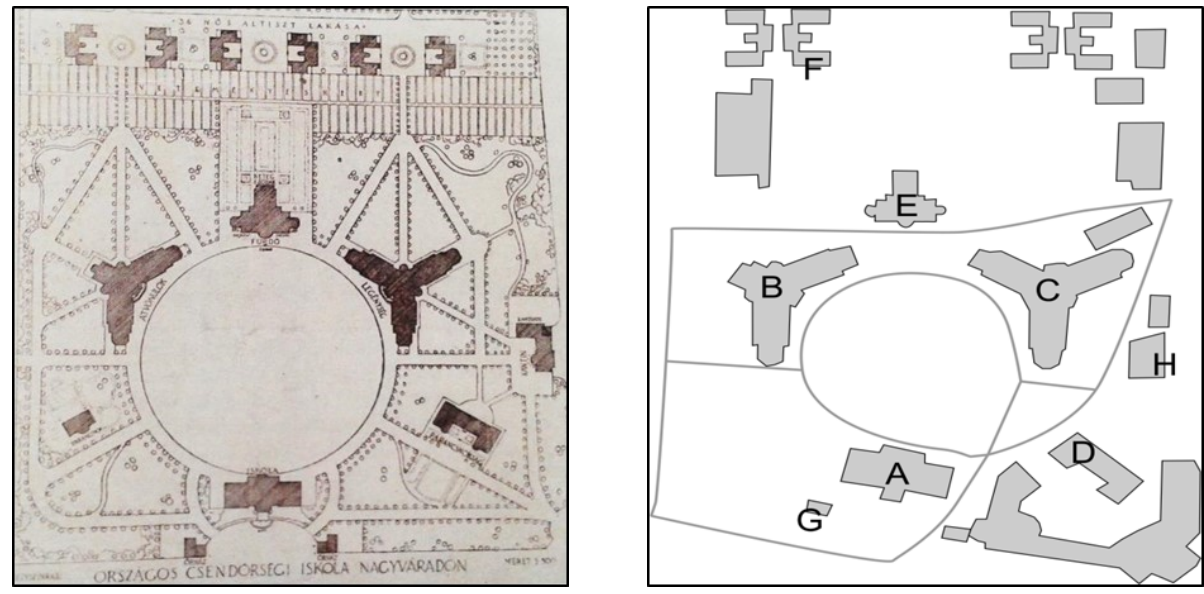

Fig. 8 - Original blueprint of the Gendarmerie in Oradea - the complex planned by József Vágó and the recent buildings of the same area

Source: Lambrich (2010), edited by the authors

Vágó made an outrageous plan for the gendarmerie, as he broke up with the traditional barrack designs and built a great central hall which represents the staircase itself (Lambrich 2010). So the functions of the military unit are combined (Fig. 9).

These buildings are considered the last work of Vágó in Oradea, and the first in this large-scale (Moravánszky 1988, Paşca 2005, Paşca 2010). Vágó mixed different architectural directions in his work. In the next paragraph we will have a brief outlook on these influences.

The buildings of the gendarmerie represent national architectural and cultural heritage monuments according to the decision no. $\mathrm{BH}-$ II-a-A-01031 of Bihor County. The decision argues that the former military site is featured by the late secessionist architecture style, thus the buildings are complexly composed in terms of architectural style.

The secession, as an artistic movement, has many names and directions across Europe. It is called Jugendstil in Germany, Modern Style in England, Secessionstil in Austria, Art Nouveau in France. In lack of a comprehensive name, we will refer as Secession to this style, in our paper (Moravánszky 1988, Loze 1992, Vadas 2005,

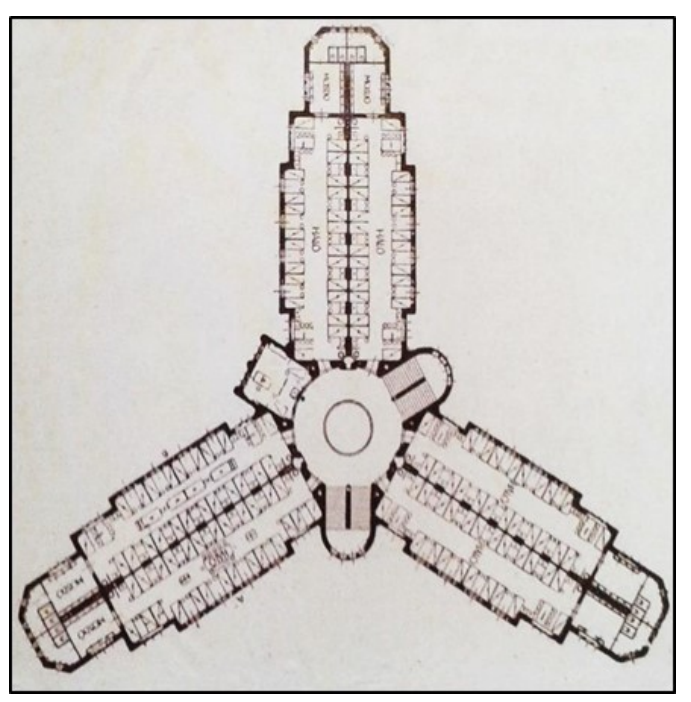

Fig. 9 - Original blueprint of the Oradean Gendramerie barrack planned by József Vágó

Source: Lambrich (2010) 
Fahr-Becker 2013).

Secession is considered the art of the line. Line is essential to express thoughts, identity and emotions. Therefore, the most important elements on the facades are the stylistic lines of the ornaments. The main decorations are naturalistic and floral adornments defined by sudden and violent, sometimes smooth and thin, curves (Tschudi-Madsen 1956). The aim of secession, as a new wave of architecture, is to express the era of the early 1900's which was created as a criticism on historicism (Moravánszky 1988). Historicism, as an architectural direction, revives historical architectural elements from the ancient Greek or romantic architecture which created the eclectic architecture. The critical intentions of secession were not fully successful, due to the conservative and strongly rooted eclecticism in the Austrian-Hungarian Empire (Vadas 2005). This required compromise between the secessionist and the historicist architecture in the beginning, therefore style continuity is an important feature of the early Austro-Hungarian secessionist buildings.

In the Hungarian Kingdom, a strong endeavour appeared to adapt the folk motives in architecture. In the early 1900's, Ödön Lechner had great impact on architecture, as he believed that secession can be a national art form for the Carpathian basin. The disciples of Lechner (Károly Kós, Lajos Kozma, Béla Lajta etc.) made pilgrimages to Transylvania to discover the forgotten folk art. They did not copy the motives, but adopted them in a $20^{\text {th }}$ century form (Vadas 2005). This influence has a strong imprint on the Hungarian and Transylvanian buildings. As a result, secession could not evolve fully in its traditional wiener form. This Transylvanian folk motive combines the modern and the traditional architecture of the Carpathians. The secession born, but folk art influenced style can be referred as Transylvanian architecture, as an unique feature of the Carpathian basin. It is not Hungarian, nor Romanian, nor German, just pure Transylvanian. This style is functional, purified and simplified, less than secession, and more than modernism. This kind of pre-modern rationalism and folk-orientation have always had greater room to appear in architecture in this area.

Due to several political changes in the Carpathian basin, the program of secession was consummed during the early 1900's. In Western Europe, other new wings started to evolve from secession, for example, the art deco. The term of art deco is originated from the Paris World Fair (Expo) in 1925, but the art stream existed since the early 1910's (Loze 1992). Originally, art deco evolved as a wing of secession movement; later, it became undoubtedly an autonomous artistic wave. The importance of lines remained, but the floristic motives and richly ornamented facades became more abstractive, stylistically simplified and geometric. Functionalism became major, and the decoration got gracefully puritan. In the AustrianHungarian Empire, the art deco just started when the First World War ended with the collapse of the dualistic state and it revoked eclecticism in architecture instead of consummating art deco (Vadas 2005). However, fortunately, the Gendarmerie complex contains some of these ideas as well. The main entrance of the main building reminds us to the roman and gothic monumentalism (Fig. 10) but in a modernist manifestation, which appears in other works of Vágó (such as Gresham-Palace, Budapest).

The facade is simple and flush, the windows are uniform with steady distance. The main building's front windows are narrow but tall, which gives elegance and a reminiscence of the gothic windows with the stained glass. This combines the historic continuity to the complex with the simplicity of modernism and envisions the traditional Transylvanian architecture.

The ground floor is covered with rectangular cement plates which reminds the spectator the plurality and the simplicity of functional modernism, rationality, and art deco. The Vágó brothers used cement flagstones (Fig. 11) in the Árkád-bazár building in Budapest, the same solution was used on the Darvas-La Roche villa, Oradea. The riveted cement coating is a hint for the modern, industrial large-scale production, the era of steel and machines (Vadas 2005). 

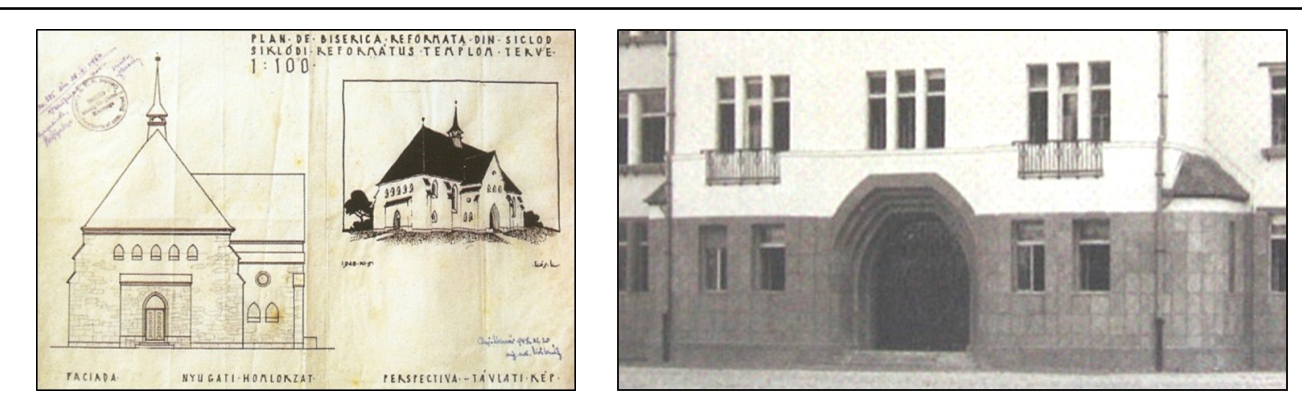

Fig. 10 - Entrance and perspective of a Transylvanian church by Károly Kós Source: www.epiteszforum.hu

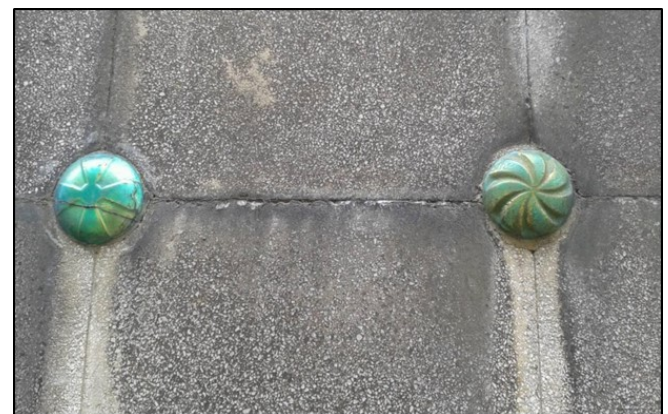

Fig. 11 - Cement flagstones on the Darvas -Laroche villa and the university buildings

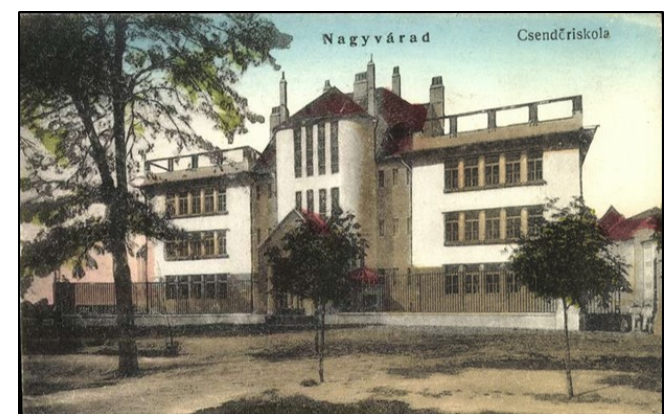

Fig. 12 - The former balconies which have been built up

Source: http://postcards.hungaricana.hu

The main building though has no specific décor on the façade, but the geometrically composed roof terraces (hinting early Bauhaus) (Fig. 12.) and the majolica tiles on the roof made the main building unique. Unfortunately, after a renovation, the terraces had been built up and the roof tiles were changed.

Inside the buildings, secessionist decorations can be found in the staircases or the handrails. Without taking notice on the original plans and the architectural guidelines, the windows and the doors have been modified to suite the building to the university role. In several cases, modern architecture and heritage were not considered as priority during the socialist times. In the next years, changes to renovate the buildings should be done according to the architectural style they were originally built in.

\section{Conclusions}

The Military Brownfields redevelopment generates the complex utilization of a region, as rehabilitation has significant positive impacts, like improving the urban aesthetics. Furthermore, these military facilities act as attractions especially based on their cultural heritage features. Many of these former military sites and buildings do not only have a historical value, remnants of an epoch of military expansion, but they also have inherent architectural and affective value and importance. Nowadays, even though several changes had been made, for example the buildings are painted in different colours, or new parts were attached and built in some cases, the buildings have still a great importance. In the recent years, new initiatives have started to renew and to restate the monuments which were abandoned in terms of cultural heritage. The common built heritage symbolizes the modernist approaches and the importance of the 
Transylvanian folk motives combined with art deco and secession which should be exploited more. Therefore, the brownfield rehabilitation project of one of the former military sites of Oradea should not only change the function of the territory, from military to academic activity, but cultural tourism should be developed based on special thematic routes that could help to increase the visitors' number and the general tourism activity as well.

Another Military Brownfield redevelopment project - the Industrial Park Eurobusiness II Oradea - is expected to open new opportunities at local and regional level, supporting in this way the functional urban-economic reintegration of the former military sites, by adding significant economic value and by balancing the land-use development process through the reuse of underutilized spaces, instead of consuming new green urban or suburban territories. The new opportunities of investment would generate positive socio-economic effects, important additional incomes, new infrastructure works, while the negative impact of the brownfield sites on the population and the urban ecosystem would decrease. The challenge for the city is to transform these abandoned military areas and the heritage buildings into successful socioeconomic examples for achieving competitiveness, while generating good practice cases for other similar projects and for overall regional development. As the public authorities in Oradea have a leading role in the territorial management at local, county or regional level, the successful socio-economic reuse actions of these military heritage sites represent a part of a major redevelopment challenging mechanism, generating spin-offs effects in a wider sustainable urban development process. Effective land restoration and reuse in the city of Oradea, require integrated actions and approaches taking into account technological, legal, organizational, social-economic, scientific, informational, architectural and spatial land planning issues, together with the involvement of all public, private and non-profit stakeholders.

An integrated framework, working as a catalyst between the local authorities, the local community, and the private investors is required for improving the socio-economic sustainable development of Oradea. As sustainable development remains a fundamental objective of the European Union under the Lisbon Agenda (European Council 2000) and further leading policy documents (European Commission 2009), specific sustainable development policies should be incorporated in the (re)development practices which conserve, protect and preserve the urban environment, minimizing the negative impacts of brownfield sites existing in the interior of urban communities.

\section{References}

BERMAN L., ORR D., FORRESTER T. (2009), Improving Community Health: Brownfields and Health Monitoring, Environmental Practice 11 (3), 190-195. BRITANNICA (2016), Korean War (1950-1953), Encyclopædia Britannica, London. COBÂRZAN B. (2007), Brownfield Redevelopment in Romania, Transylvanian Review of Administrative Sciences 21E, 28-46.

COCEAN P. (2005), Geografie regională, Presa Universitară Clujeană, Cluj-Napoca.

DE SOUSA C., GHOSHAL S. (2012), Redevelopment of brownfield sites, in: Zeman F. (ed.), Metropolitan sustainability: Understanding and improving the urban environment, Woodhead Publishing, Cambridge, pp. 99-117.

EUROPEAN COMMISSION (2009), Mainstreaming sustainable development into EU policies: 2009 Review of the European Union Strategy for Sustainable Development, European Commission, Brussels.

EUROPEAN COUNCIL (2000), The Lisbon Agenda, European Council, http:// www.consilium.europa.eu/.

FAHR-BECKER G. (2013), Szecesszió, Vince Kiadó, Budapest.

GRIMSKI D., FERBER U. (2001), Urban brownfields in Europe, Land Contamination and Reclamation 9 (1), 143-148.

ILIEȘ A., WENDT J. (coord.) (2003), Europe between millenniums. Political Geography 
Studies, Editura Universitătii din Oradea, Oradea.

INSSE (2015), Statistical data on population, National Institute of Statistics, Bucharest. LAMBRICH A. (2005), Vágó József, Holnap Kiadó, Budapest.

LOCAL HISTORY (2016), Divizia 11 Infanterie - repere istorice, Local History@Your Public Library, http://www.istorielocala.ro/.

LOZE P. (1992), Le style Art Déco, Flammarion, Paris.

MÂNDRUṬ S. (2013), The Vienna Arbitrage / Diktat, in the present Romanian Historiog-

raphy. Ethics "versus" History (1989-2010), Annals of the Academy of Romanian Scientists.

Series on History and Archeology, 5 (2), 129-150.

MICHALSKI T. (2006), A Geographic Approach to the Transformation Process in European Post-Communist Countries, in: Michalski T. (ed.), The Geographical Aspects of the Transformation Process in Central and East-Central Europe, Wydawnictwo Bernardinum, Gdynia-Pelplin, pp. 7-26.

MONUMENTE BIHOR (2014), Monumente din judeṕıl Bihor, Fundația pentru Protejarea Monumentelor Istorice din Judetul Bihor, http://www.monumentebihor.ro/. MORAVÁNSZKY Á. (1988), Építészet az Osztrák-Magyar Monarchiában, Corvina Kiadó, Budapest.

NATO (1949), The Washington Treaty, NATO, Washington D.C.

ORADEA CITY HALL (2011), Plan Urbanistic Zonal - Parcul Industrial Eurobusiness II Oradea, Consiliul Local al Municipiului Oradea, Oradea.

ORADEA CITY HALL (2013), Planul Urbanistic General Oradea. Etapa 2: Concept general de dezvoltare urbană, Oradea City Hall, Oradea. OSCE (1990), Treaty on Conventional Armed Forces in Europe, OSCE, Vienna. PAŞCA M. (2005), Operele arhitecţilor Vágó József şi Vágó László la Oradea, Editura Tipo MC, Oradea. PAŞCA M. (2010), Oradea around 1900, Editura Arca, Oradea. PÉTER I. Z. (2008), Nagyvárad müemlék épületei, Nagyvárad, PBMET.

RUSS T. H. (2000), Redeveloping Brownfields: Landscape Architects, Site Planners, Developers, McGraw-Hill, New York.

SARNI W. (2009), Greening Brownfields: Remediation through Sustainable Development, McGraw-Hill, New York. TOH (2016), The Warsaw Treaty Organization (1955), The Office of the Historian, Washington D.C. TSCHUDI-MADSEN S. (1956), The Sources of Art Nouveau, Aschehoug, Oslo. U.S. SENATE (2002), Comprehensive environmental response, compensation, and liability act of 1980 "Superfund", United States Code, 487-653. VADAS J. (2005), A magyar art deco - Stílusok - korszakok, Corvina Kiadó, Budapest.

Initial submission: 20.10 .2015

Revised submission: 28.04.2016

Final acceptance: 19.06.2016

Correspondence: Department of Geography, Tourism and Territorial Planning, University of Oradea, 1 Universității Street, 410087 Oradea, Romania.

Email: cezarmorar@yahoo.com 